\title{
Anti-inflammatory and immunomodulating properties of the herbal preparation indicated for prevention and treatment of alopecia
}

This article was published in the following Dove Press journal:

Botanics: Targets and Therapy

I October 2013

Number of times this article has been viewed

\author{
Alexander Yu Galkin ${ }^{1,2}$ \\ Valentine F Solovjova ${ }^{3}$ \\ Alex M Dugan' \\ 'Department of Industrial \\ Biotechnology, Faculty of \\ Biotechnology and Bioengineering, \\ National Technical University of \\ Ukraine "Kyiv Polytechnic Institute", \\ Kyiv, Ukraine; ${ }^{2}$ Research and \\ Development Department, PRO- \\ PHARMA Company, LLC, Kyiv, \\ Ukraine; ${ }^{3}$ Laboratory of Hygiene \\ Expertise, Ukrainian Research \\ Institute of Nutrition, Biotechnology \\ and Pharmacy, Kyiv, Ukraine
}

Background: Alopecia is a chronic inflammatory disease, in which the hair follicles become damaged. The etiology of the disease is still little known; the most common cause of alopecia is likely an autoimmune mechanism. Medicinal herbs (Arctium lappa roots, Sophora japonica fruits, Acorus calamus roots, Urtica dioica leaves, Humulus lupulus fruits) are promising remedies for the prevention and treatment of alopecia.

Methods: Anti-inflammatory properties of the phytopreparation were investigated using the following models: "rigid" inflammatory model and model of adrenalin pulmonary edema (antiexudative activity), as well as the "cotton granuloma" model (influence on proliferative effects). Immunomodulatory properties were studied by analyzing the metabolic activity of macrophages exposed to herbal preparation as well as the secretion of monocyte-derived cytokines.

Results: Intragastric administration of the herbal preparation reduced severity of the exudation phase of inflammation in the limbs of animals (37.3\%) and inhibited pulmonary edema $(21.0 \%)$. It was demonstrated that the phytopreparation reduced the weight of the granulation-fibrous tissue by $50.6 \%$. The phytopreparation activated macrophages $(50-400 \mu \mathrm{g} / \mathrm{mL})$, decreased the number of flattened cells, increased the number of rounded cells and increased the production of oxidative metabolites (by $26 \%$ compared with intact cells). The herbal drug $(0-300 \mu \mathrm{g} / \mathrm{mL})$ increased cytokines secretion by human blood cells (interleukin-2 and interferon- $\gamma$ ).

Conclusion: The phytopreparation exhibited moderate anti-inflammatory and immunomodulating properties. It is promising for the prevention and treatment of alopecia.

Keywords: herbal preparation, Arctium lappa, Sophora japonica, Acorus calamus, Urtica dioica, Humulus lupulus

\section{Background}

Alopecia (hair loss) remains a very real problem and is one of the most common diseases in skin pathology. ${ }^{1}$ Additionally, this condition of hairs, which are appendages of the skin, often affects a person's destiny because people may experience psychological disorders (irritability, unsociability, inactive lifestyle) due to this cosmetic defect. It is important to note that a single conception of alopecia pathogenesis does not currently exist and a variety of its clinical signs have not been fully explained yet. Therefore, the treatment problem has not been completely solved. ${ }^{2}$

There are congenital and acquired forms of alopecia (alopecia areata, diffuse, androgenic, toxic, traumatic, scarring, syphilitic alopecia, leprous, symptomatic, etc). ${ }^{3-6}$ Alopecia areata is the most common form of acquired alopecia, which can develop at any age, both in males and females. The etiology of alopecia areata is not completely established. The pathogenesis is rather complicated, because it is based on various pathogenic
Correspondence: Alexander Yu Galkin Peremogy av., 37, bldg. 4, Kyiv, 03056, Ukraine

Tel +38044502 7900

Fax +38044502 7900

Email alexfbt@gmail.com (c) (i) (5) 2013 Galkin et al. This work is published by Dove Medical Press Ltd, and licensed under Creative Commons Attribution - Non Commercial (unported, v3.0) License. The full terms of the License are available at http://creativecommons.org/licenses/by-nd/3.0/. Non-commercial uses of the work are permitted without any further Dove Medical Press Ltd, provided the work is properly attributed. Permissions beyond the scope of the License are administered by Dove Medical Press Ltd. Information on how to request permission may be found at: http://www.dovepress.com/permissions.php 
mechanisms, which include central nervous system disorders, namely diseases of brain suprasegmental structures, as well as psychogenic, diencephalic, neuroreceptory, and vegetative disorders. ${ }^{6,7}$ Recently, the leading role of immune and autoimmune disorders in alopecia areata pathogenesis was established. In particular, the central role of cytokines in the mechanism of baldness development was confirmed by a finding of a decrease of interleukin-4 and interleukin-2 (IL-2) levels in patients with a severe form compared to the control group, which may indicate the lowering of T-helper functional activity. ${ }^{8}$ There were signs of secondary immunodeficiency conditions accompanied by depression of the T-cell chain of immunity, inhibition of phagocytal and metabolic activity of peripheral blood cells, increase of B-lymphocyte numbers, concentration of $\operatorname{IgG}, \operatorname{IgM}$, and IgA immunoglobulins, as well as circulating immune complexes. ${ }^{9}$

During the preliminary stages of the study, we created the pharmacotherapeutic and phytochemical design of the herbal preparation for prevention and treatment of alopecia. ${ }^{10,11}$ This preparation was a complex tincture made of a combination of medical herbs including Arctium lappa roots, Sophora japonica fruits, Acorus calamus roots, Urtica dioica leaves, and Humulus lupulus fruits (cones). The most important pharmacologically active substances of the herbal preparation were flavonoids $(0.27 \%$ to $0.31 \%)$, polyphenols $(0.17 \%$ to $0.18 \%)$, hydrocinnamic acids $(0.10 \%$ to $0.13 \%)$, and polysaccharides $(0.40 \%$ to $0.49 \%)$ (data are given in terms of dry substance basis). ${ }^{10}$ The herbal preparation was standardized for flavonoids content in terms of rutin (not less than $0.25 \%$ ). Biologically active substances of these herbs are characterized by anesthetic, antipruritic, antiseptic, and epithelizing properties - they restore skin structure and functions, facilitate circulation in the skin capillary system, stimulate skin metabolism, and enhance scalp nutrition. ${ }^{10,11}$

The goal of the study includes the determination of antiinflammatory and immunomodulating activity of the herbal preparation indicated for the prevention and treatment of alopecia. The study described below was conducted with a semi-industrial batch of herbal preparation produced in the production department of PRO-PHARMA Company (Kyiv Region, Ukraine).

\section{Methods}

\section{Plant material}

Medicinal plants were harvested in 2006 in the Kiev and Kharkiv Regions of Ukraine (Arctium lappa and Acorus calamus roots in October, Humulus lupulus fruits and Urtica dioica leaves in June), and in the Crimea Region of Ukraine
(Sophora japonica fruits in September). ${ }^{12}$ The plants were identified by Dr A Kotov (Ukrainian scientific pharmacopoeial center for quality of medicines, Kharkiv, Ukraine) according to the European Pharmacopoeia, 5th edition, and self developed methods. ${ }^{13-15}$

\section{Preparation techniques and standardization}

The phytopreparation was a complex tincture of medicinal plants which included (per $100 \mathrm{~g}$ ): Arctium lappa roots (28 g), Sophora japonica fruits (28 g), Acorus calamus roots (16 g), Urtica dioica leaves (14 g), Humulus lupulus fruits (cones) (14 g). Herbal raw materials were crushed by the laboratory mill to a particle size of $3-5 \mathrm{~mm}$. The ratio of raw materials to finished product was 1:5; the extractant was ethanol $40 \%$. Extraction was carried out at room temperature by fractional maceration (the duration of one extraction was 12 hours).

The following parameters were standardized for the phytopreparation: identification of terpenoids, flavonoids (hydroxycinnamic acids), amino acids, and polyphenolic compounds; dry residue (not less than 3.5\%); ethanol content (33\%-36\%); heavy metals (not less than $0.001 \%$ ); assay (content of flavonoids in terms of routine - not less than $0.25 \%$ ); microbiological purity - in accordance with national part of monograph 5.1.4 of the State Pharmacopoeia of Ukraine (total number of aerobic microorganisms: not more than $10^{3}$ bacteria and $10^{2}$ fungi per $1 \mathrm{~mL}$, absence of Enterobacteriaceae bacteria, Staphylococcus aureus, and Pseudomonas aeruginosa in $1 \mathrm{~mL}) .{ }^{16,17}$ A previously dealkalized preparation was used.

\section{Study of anti-inflammatory properties}

Experiments were performed on white nonlinear female mice weighing 18-22 g. The mice were divided into seven groups with ten animals in each group. The mice were kept under standard vivarium conditions at a temperature of $20^{\circ} \mathrm{C}-24^{\circ} \mathrm{C}$ and relative humidity of $30 \%-70 \%$; the animals consumed food and water ad libitum.

An investigation of the anti-exudative action of the herbal preparation was performed on the "rigid" inflammatory model (limb edema caused by subplantarly injection of a $2 \%$ formalin solution). ${ }^{18}$ The study preparation was administered as a single intragastric dose. The control animals received purified water in the equivalent amount. Sodium diclofenac was used as a reference at a dose of $2.5 \mathrm{mg} / \mathrm{kg}$, corresponding to its effective dose.

An evaluation of the anti-exudative action of the herbal preparation was also carried out on the adrenal lung 
swelling model. ${ }^{19}$ The herbal tincture was administered as a single intragastric dose. The control animals received purified water in the equivalent amount. The herbal preparation activity was compared with the anti-exudative action of sodium diclofenac $(2.5 \mathrm{mg} / \mathrm{kg})$. The study animals received the herbal preparation intragastrically 1 hour prior to the experiment.

An evaluation of the herbal preparation effect on the proliferative component of the inflammatory reaction was performed on the cotton pellet granuloma model. ${ }^{20}$

\section{Study of immunomodulating properties}

To investigate the effect of the herbal preparation on tissue macrophages, we collected peritoneal exudate cells (PEC) by washing the abdomen cavity of Balb/c mice with $10 \mathrm{~mL}$ of 199 medium (Biomed, Moscow, Russia). PEC obtained from $10-15$ mice at a concentration of $(2.0-2.5) \times 10^{6}$ per $1 \mathrm{~mL}$ were collected into siliconized vials, stirred, and 1.5-2.0 mL was poured into plastic Petri dishes (diameter $35 \mathrm{~mm}$ ) and incubated for 2 hours at $37^{\circ} \mathrm{C}$ in a humidified atmosphere with $5 \% \mathrm{CO}_{2}$. After the incubation procedure, cells that did not stick to the plastic were washed away and adhered cells were additionally rinsed with 199 medium. After rinsing, we added $1.5 \mathrm{~mL}$ of complete RPMI-1640 medium (PanEco, Moscow, Russia), which contained the herbal preparation at a concentrations of $50-400 \mu \mathrm{g}$ per $1 \mathrm{~mL}$, and incubated it according to the mentioned conditions for 24 hours. When the incubation was completed the unattached cells were deleted. The adhered macrophages were fixed with $96 \%$ ethanol and stained with azurite and eosin. The cell content was evaluated under a microscope in transmitted light (magnification $1,000)$, by calculating the macrophage percentage in ten fields of vision and differentiating them according to their size (large, medium, or small) and shape (round or flat).

Production of oxide radicals by macrophages was studied as follows. One milliliter of the PEC suspension, obtained as described above, was poured into chemiluminograph vials and incubated at $37^{\circ} \mathrm{C}$ in the humidified atmosphere of $5 \% \mathrm{CO}_{2}$ for 2 hours. After incubation the unattached cells were washed away. The cells that adhered to vial walls were washed two times with 199 medium. Vials were filled with $1 \mathrm{~mL}$ of complete RPMI-1640 medium containing the herbal preparation at a concentration of 50 to $400 \mu \mathrm{g}$ per $1 \mathrm{~mL}$ and incubated at the abovementioned conditions for another 24 hours. After incubation the supernatant fluid was removed, $0.5 \mathrm{~mL}$ of the buffer solution ( $\mathrm{pH} 7.2)$, prepared from Hanks' solution (phenol red) supplemented with $5 \mathrm{mM}$ of glucose, as well as $10 \mathrm{mM}$ of HEPES-buffer and $0.62 \mathrm{mM}$ of luminal (Sigma-Aldrich, St Louis, MO, USA) were added and the level of spontaneous and zymosan-induced chemiluminescence was analyzed.

To study the effect of the herbal preparation on human blood cells, blood samples were collected from healthy fasting donors in the morning from their median cubital vein into vials with sodium heparin using the Vacutainer system (Becton Dickinson, Franklin Lakes, NJ, USA). The blood samples were used not later than 6 hours after collection. The herbal preparation was diluted at a concentration of $1 \mathrm{mg} / 1 \mathrm{~mL}$ in RPMI-1640 medium and filtrated (filter pore size $0.22 \mu \mathrm{m}$ ). The necessary preparation of dissolutions in the complete RPMI-1640 medium at a dosage range of 50 to $300 \mu \mathrm{g} / \mathrm{mL}$ was prepared. The obtained substance $(0.2 \mathrm{~mL})$ was distributed into wells of a 48-well plate for cells cultivation (Nunc, Roskilde, Denmark). For the negative control, $0.2 \mathrm{~mL}$ of complete RPMI-1640 medium was added. All wells were filled with $0.2 \mathrm{~mL}$ of whole heparinized blood. Samples were incubated at $37^{\circ} \mathrm{C}$ in atmosphere with $5 \% \mathrm{CO}_{2}$ for $6-48$ hours. After incubation, $0.2 \mathrm{~mL}$ of the cultural fluid was poured into $0.5 \mathrm{~mL}$ centrifugal tubes and centrifuged at 10,000 rpm for 15 minutes. The supernatant fluid was frozen at $-70^{\circ} \mathrm{C}$ and stored for cytokines content determination. Monocytic cytokines secretion was studied by enzyme-linked immunosorbent assay (ELISA) in the cultural medium. Cytokine concentration was measured using the following kits: reagents kit for $\gamma$-interferon concentration immunoenzymatic assay in human biological fluids and cultural media (Gamma-InterferonELISA-BEST), reagents kit for $\alpha$-interferon immunoenzymatic assay in human biological fluids and cultural media (Alpha-Interferon-ELISA-BEST), reagents kit for tumor necrosis factor- $\alpha$ concentration immunoenzymatic assay in human biological liquids and cultural media (Alpha-TNFELISA-BEST), reagents kit for interleukin-8 (IL-8) concentration immunoenzymatic assay in human biological fluids and cultural media (IL-8-ELISA-BEST), reagents kit for IL-2 concentration immunoenzymatic assay in human biological fluids and cultural media (IL-2-ELISA-BEST), and reagents kit for interleukin-1 (IL-1) beta concentration immunoenzymatic assay in human biological fluids and cultural media (IL-1 beta-ELISA-BEST) (Vector-Best, Novosibirsk, Russia). Reaction intensity was determined using the immunoenzymatic analyzer-photometer Multiskan Ascent 354 (Thermo Labsystems, Massachusetts, USA).

\section{Mathematical methods}

Statistical analysis of the results was performed using Student's $t$-test and Pearson correlation coefficients. ${ }^{21}$ 
Data presented as mean \pm standard deviation. The difference between the studied parameters was considered statistically significant at a value of $P \leq 0.05$.

\section{Bioethical principles}

All animal studies were performed in accordance with the recommendations of the European Convention for the Protection of Vertebrate Animals used for Experimental and other Scientific Purposes and approved by the Institutional Animal Care and Use Committee.

\section{Results and discussion}

The results of the herbal preparation's anti-exudative action on the "rigid" inflammatory model are presented in Table 1. It was found that the herbal preparation inhibited the intensity of the exudation phase of the inflammation process. The anti-exudative action of the tested tincture was 4.64 times lower compared to the effect of the reference preparation (sodium diclofenac). Intragastric administration of the herbal preparation resulted in a $37.3 \%$ reduction of the intensity of the exudative reaction caused by the subplantar injection of a $2 \%$ formalin solution. In the case of sodium diclofenac, an $86.5 \%$ decrease of limb volume was observed.

The same results were obtained after evaluating the anti-exudative action of the tincture using the adrenalin lungs edema model. The effect of the herbal preparation was compared to the anti-exudative action of sodium diclofenac $(2.5 \mathrm{mg} / \mathrm{kg})$. The test herbal preparation was administered to the study animals intragastrically 1 hour prior to the experiment. The obtained data are presented in Table 2. It was found that the herbal preparation inhibited the intensity of lungs edema in the study animals to $21 \%$, which was inferior to the comparative preparation activity.

The herbal preparation effect on the proliferation component of inflammatory reaction was evaluated on the "cotton granuloma" model (Table 3). The analysis of the obtained data

Table I Effect of the herbal preparation on the exudative phase of the inflammation process (formalin edema model)

\begin{tabular}{llll}
\hline Preparation & Dosage & \multicolumn{2}{l}{ Change of limb volume } \\
\cline { 2 - 4 } & & $\begin{array}{l}\text { Absolute } \\
\text { value }(\mathrm{g}) *\end{array}$ & $\begin{array}{l}\text { Percentage of } \\
\text { the control (\%) }\end{array}$ \\
\hline Control (purified water) & $2.0 \mathrm{~mL} / \mathrm{kg}$ & $0.88 \pm 0.12$ & 100.0 \\
Sodium diclofenac & $2.5 \mathrm{mg} / \mathrm{kg}$ & $0.12 \pm 0.01$ & 13.5 \\
Herbal preparation & $2.0 \mathrm{~mL} / \mathrm{kg}$ & $0.55 \pm 0.09$ & 62.7 \\
\hline
\end{tabular}

Notes: Each group contains ten animals. Difference from the control is statistically significant $(P<0.05)$. *Values are presented as mean \pm standard deviation.
Table 2 Effect of the herbal preparation on the exudation phase of the inflammation process (adrenalin lungs edema model)

\begin{tabular}{llll}
\hline Preparation & Dosage & \multicolumn{2}{l}{ Lung coefficient } \\
\cline { 3 - 4 } & & $\begin{array}{l}\text { Absolute } \\
\text { value (g)* }\end{array}$ & $\begin{array}{l}\text { Percentage of } \\
\text { the control (\%) }\end{array}$ \\
\hline Intact animals & - & $0.69 \pm 0.08$ & 39.7 \\
Control (purified water) & $2.0 \mathrm{~mL} / \mathrm{kg}$ & $1.74 \pm 0.12$ & 100.0 \\
Sodium diclofenac & $2.5 \mathrm{mg} / \mathrm{kg}$ & $1.02 \pm 0.01$ & 58.6 \\
Herbal preparation & $2.0 \mathrm{~mL} / \mathrm{kg}$ & $1.37 \pm 0.09$ & 79.0 \\
\hline
\end{tabular}

Notes: Each group contains ten animals. Difference from the control is statistically significant $(P<0.05)$. *Values are presented as mean \pm standard deviation.

showed that the reference preparation, sodium diclofenac, inhibited the proliferation process to $75 \%$ compared to the control; the antiproliferative effect of the tested preparation was inferior and amounted to a 50.6\% inhibition compared to the control.

Therefore, the herbal preparation possessed an antiinflammatory action. It could also provide anti-exudation and antiproliferative effects.

The results of the evaluation of the herbal preparation's biological activity were also informative. It was found that mice tissue macrophages obtained from the peritoneal exudate could be activated during their in vitro cultivation with the herbal preparation. Macrophages activation is presented as a change of their size and shape as well as their metabolic and enzymatic activity.

PEC was obtained from Balb/c mice and incubated with the herbal preparation. The analysis of the macrophages morphological specifications showed a reduction of flat forms of macrophages with a simultaneous increase of round shape cells under the effects of the herbal preparation. At the same time, doubling of the percentage of large rounded macrophages was noticed. This confirms activation of big tissue macrophages population under direct in vitro effects of the herbal preparation on cells.

Table 3 Effect of the herbal preparation on the proliferation phase of the inflammation process (cotton granuloma model)

\begin{tabular}{lccl}
\hline Preparation & Dosage & \multicolumn{2}{l}{$\begin{array}{l}\text { Weight of the granulation- } \\
\text { fibrous tissue }\end{array}$} \\
\cline { 3 - 4 } & & $\begin{array}{l}\text { Absolute } \\
\text { value }(\mathbf{m g}) *\end{array}$ & $\begin{array}{l}\text { Percentage } \\
\text { change } \\
\text { to control (\%) }\end{array}$ \\
\hline Control (purified water) & $2.0 \mathrm{~mL} / \mathrm{kg}$ & $139.8 \pm 7.6$ & 100.0 \\
Sodium diclofenac & $2.5 \mathrm{mg} / \mathrm{kg}$ & $35.6 \pm 7.5$ & 75.0 \\
Herbal preparation & $2.0 \mathrm{~mL} / \mathrm{kg}$ & $70.7 \pm 6.1$ & 50.6 \\
\hline
\end{tabular}

Notes: Each group contains ten animals. Difference from the control is statistically significant $(P<0.05)$. *Values are presented as mean \pm standard deviation. 


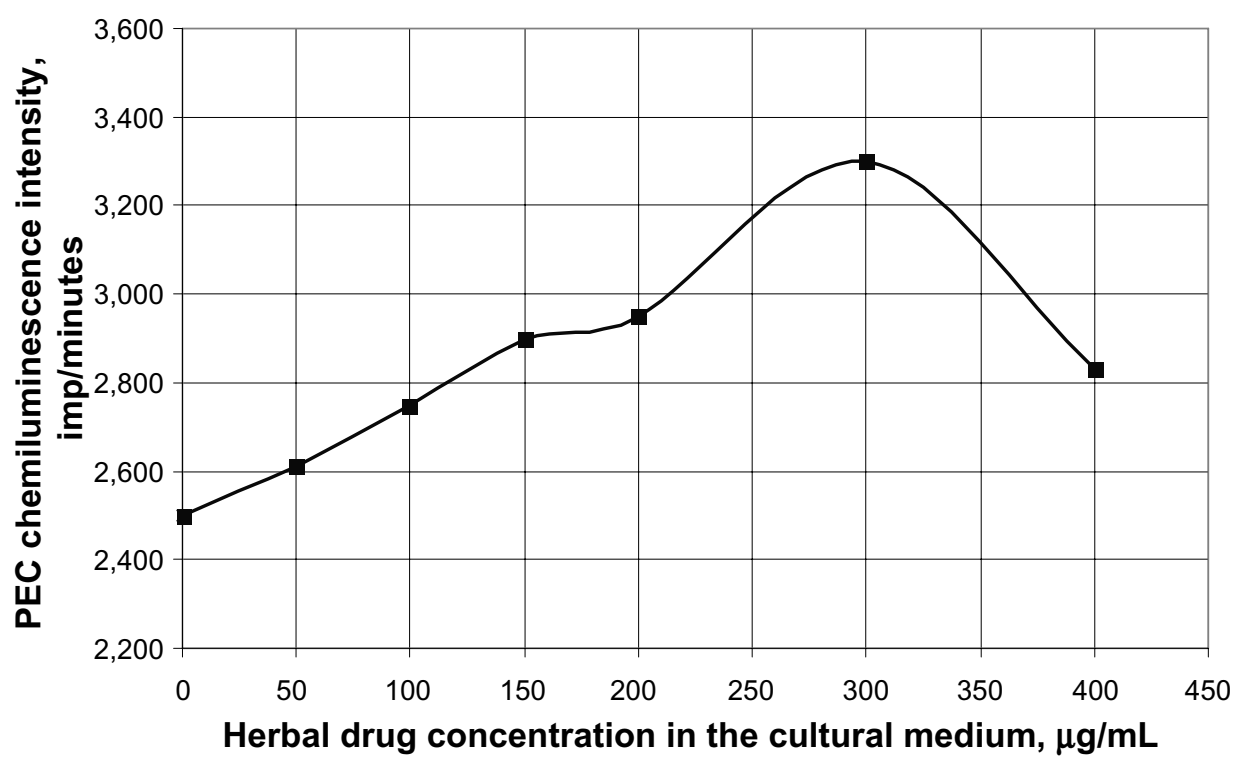

Figure I Chemiluminescence intensity of peritoneal exudation of cells in response to opsonized zymosan after preliminary cultivation of cells with the herbal preparation. Abbreviations: imp, number of impulses; PEC, peritoneal exudate cells.

The activating effect on macrophages was registered in a wide range of herbal preparation concentrations from 50 to $400 \mu \mathrm{g} / \mathrm{mL}$.

Macrophages encountering microorganisms produce peroxides and oxide radicals, with the aid of which the macrophages can effectively eliminate the microorganisms. This is one of the most effective ways that macrophages provide protection. It was found that the herbal preparation increased macrophage ability in producing oxide metabolites when contacting microorganism components.

The results of the study of the herbal preparation's effect on the production of active radicals and peroxides according to chemiluminescence intensity are shown in Figure 1 (chemiluminescence intensity of peritoneal exudate cells calculated from the results of experiments in four repetitions, $P<0.05$ ). Incubation of peritoneal macrophages with

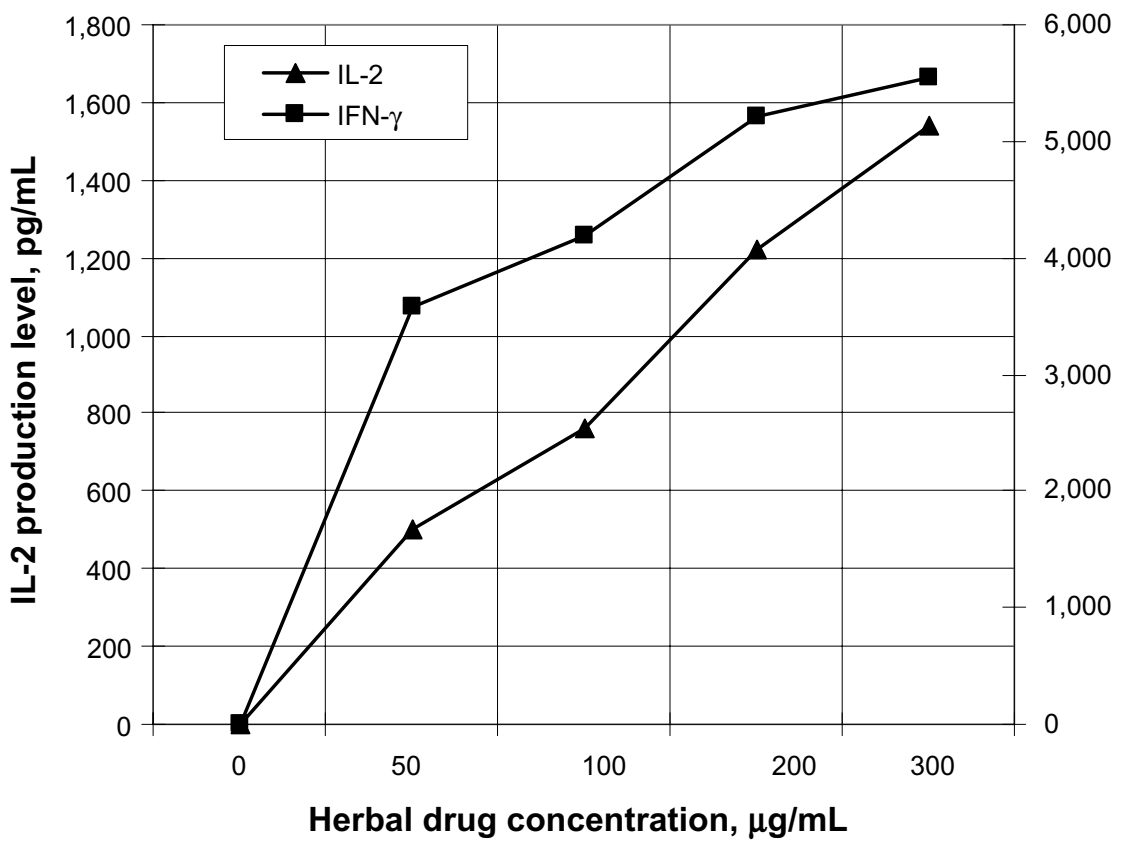

Figure 2 Cytokines content in the cultural medium of human peripheral blood cells in 12 hours (IL-2) and 48 hours (IFN- $\gamma$ ) after incubation with the herbal preparation. Abbreviations: IFN- $\gamma$, interferon- $\gamma$; IL-2, interleukin-2. 
the herbal preparation for 24 hours did not affect the level of their spontaneous chemiluminescence, but remarkably increased (up to $26 \%$ ) the ability of the cells to produce oxide metabolites in response to zymosan. In this case, escalation of chemiluminescence activity occurred gradually in the herbal preparation with concentration ranges from 50 to $200 \mu \mathrm{g} / \mathrm{mL}$. The maximum effect was reached at $300 \mu \mathrm{g} / \mathrm{mL}$ and was wellcorrelated with herbal preparation concentration, resulting in a maximum macrophage activation if their morphological properties were taken into account. Reduction of chemiluminescence activity of macrophages in the case of continuous herbal preparation concentration increase was associated with an increase of its toxic effect on cells as evidenced by toxicological studies of the herbal preparation (data is not shown in the current article). ${ }^{22}$

When analyzing the secretion of monocytic cytokines during their cultivation in the medium with the herbal preparation, we discovered its evident effect on interferon- $\gamma($ IFN- $\gamma$ ) and IL-2 production. No effects of the herbal preparation on interferon- $\alpha$, tumor necrosis factor- $\alpha$, IL-1, and IL- 8 secretion were observed. Figure 2 shows the dose-dependent production of IFN- $\gamma$ and IL- 2 by human monocytes based on the herbal preparation concentration (cytokines content was calculated according to the results of experiments in four repetitions, $P<0.05)$.

Natural killers and macrophages also produce IL-2. The abovementioned results of tissue macrophages activity, which changed under the herbal preparation effect, are fully compatible with the results of the cytokines secretion study. It is important to note that immune interferon stimulates production of IL- $2,{ }^{22}$ so the correlation between IFN- $\gamma$ and IL-2 synthesis induction obtained in the study is entirely natural. The obtained findings indirectly indicate that the stimulation of the T-helper immunity chain by the herbal preparation is important for increasing the ratio of CD4/ CD8 cells in the epithelium of hair follicles and decreasing cell apoptosis. ${ }^{23-26}$

\section{Conclusion}

Pharmacological studies have shown that the anti-inflammatory properties of the herbal preparation due to anti-exudative and antiproliferative effects could be related to the presence of flavonoids and tannins. We found moderate immunostimulative activity of the herbal preparation on cells of the monocyte group, which was confirmed by the morphologic-metabolic activation of macrophages and an increase of IL-2 and immune interferon production by human monocytes (in vitro).

\section{Disclosure}

The authors report no conflicts of interest in this work.

\section{References}

1. Köse ÖK, Güleç AT. Clinical evaluation of alopecias using a handheld dermatoscope. J Am Acad Dermatol. 2012;67(2): 206-214.

2. Alkhalifah A, Alsantali A, Wang E, McElwee KJ, Shapiro J. Alopecia areata update: part II. Treatment. J Am Acad Dermatol. 2010;62(2): 191-202, quiz 203.

3. Assouly P. Alopecia areata. EMC - Dermatología. 2006;40(2):1-15. http://www.sciencedirect.com/science/article/pii/S1761289606464.

4. Lew BL, Shin MK, Sim WY. Acute diffuse and total alopecia: A new subtype of alopecia areata with a favorable prognosis. $J$ Am Acad Dermatol. 2009;60(1):85-93.

5. Pruvost C, Reygagne P. Alopecias cicatriciales. EMC - Dermatología. 2009;43(3):1-13. http://www.sciencedirect.com/science/article/pii/ S1761289609703425.

6. McDonagh AJG, Messenger AG. The aetiology and pathogenesis of alopecia areata. J Dermatol Sc. 1994;7(1):S125-S135.

7. Alkhalifah A, Alsantali A, Wang E, McElwee KJ, Shapiro J. Alopecia areata update: part I. Clinical picture, histopathology, and pathogenesis. J Am Acad Dermatol. 2010;62(2):177-188, quiz 189.

8. Gilhar A, Kalish RS. Alopecia areata: a tissue specific autoimmune disease of the hair follicle. Autoimmun Rev. 2006;5(1):64-69.

9. McMichael AJ. The genetic epidemiology and autoimmune pathogenesis of alopecia areata. J Eur Ac Dermatol Venereol. 1997;9(1): $36-43$.

10. Galkin OYu, Kotov AG. Study of biologically active substances content in herbal preparation for the treatment and prevention of alopecia. Ukrainian J Clin Lab Med. 2011;6(1):60-63.

11. Galkin OYu, Bondarenko LB. [Features of pharmacotherapy of alopecia areata]. Ecolog Med Genetics Clin Immunol. 2011;1(103);286299. Ukrainian.

12. Dudchenko LG, Harnyk TP, Shurayeva TK. [Harvesting of medicinal plants]. Phytotherapy. 1999;3-4:58-65. Ukrainian.

13. European Pharmacopoeia Commission, Council of EuropeEuropean Department for the Quality of Medicines. European Pharmacopoeia. 5th ed. Strasburg: Balogh Scientific Books; 2004.

14. Galkin OYu, Kotov AG. [Development of methodology for identification and quantitative determination of flavonoids in the fruits of Sophora Japonica L]. Pharmaceutical Review. 2011;4:77-81. Ukrainian.

15. Galkin OYu, Kotov AG. [Pharmacognostic study and standardization of roots of Arctium Lappa L]. Ukrainian Med Almanac. 2011;14(1):55-57. Ukrainian.

16. Scientific and Expert Pharmacopoeial Centre. The State Pharmacopoeia of Ukraine. 1st ed. Kharkiv: RIREG; 2001.

17. Galkin OYu, Kotov AG. [Development of quality control methods and analysis of herbal medicines for the treatment and prevention of alopecia]. Ukrainian J Clin Lab Med. 2011;6(2):115-119. Ukrainian.

18. Heidari MR, Foroumadi A, Noroozi H, Samzadeh-Kermani A, Azimzadeh BS. Study of the anti-inflammatory and analgesic effects of novel rigid benzofuran-3, 4-dihydroxy chalcone by formalin, hotplate and carrageenan tests in mice. Pak J Pharm Sci. 2009;22(4): 395-401.

19. Talero E, Di Paola R, Mazzon E, et al. Anti-Inflammatory effects of adrenomedullin on acute lung injury induced by carrageenan in mice. Mediators of Inflammation. 2012;2012:1-13.

20. Bailey PJ, Sturm A, Lopez-Ramos B. A biochemical study of the cotton pellet granuloma in the rat: Effects of dexamethasone and indomethacin. Biochem. Pharmacol. 1982;31(7):1213-1218.

21. Artjuhov VG, Pantyavyn AA. [Mathematical methods in biology]. Handbook. Voronezh University. 2007. Russian. 
22. Galkin OYu, Dugan OM. Materialy VII Mezinarodni vedecko-prakticka conference "Veda a technologie: krok do budouchnosti. Praha: Publishing House "Education and Science" s.r.o.; 2011:23-25.

23. Nakamura K, Okamura H, Wada M, Nagata K, Tamura T. Endotoxininduced serum factor that stimulates gamma interferon production. Infect Immunol. 1989;57(2):590-595.

24. Mayewski BBJ, Koh MS, Taylor DR, Watson B, Rhodes EL. Increased ratio of helper to supressor T-cell in alopecia areata. Br J Dermatol. 1984;110(2):171-175.
25. Simonetti O, Lucarini G, Bernardini ML, Simoncini C, Biagini G, Offidani A. Expression of vascular endothelial growth factor, apoptosis inhibitors (survivin and p16) and CCL27 in alopecia areata before and after diphencyprone treatment: an immunohistochemical study. $\mathrm{Br} J$ Dermatol. 2004;150(5):940-948.

26. Herbst V, Zöller M, Kissling S, Wenzel E, Stutz N, Freyschmidt-Paul P. Diphenylcyclopropenone treatment of alopecia areata induces apoptosis of perifollicular lymphocytes. Eur J Dermatol. 2006;16(5):537-542.

Botanics: Targets and Therapy

\section{Publish your work in this journal}

Botanics: Targets and Therapy is an international, peer-reviewed, open access journal focusing on the discovery and development of active compounds based upon or found naturally occurring in the plant kingdom that may have therapeutic potential in any disease state. The manuscript management system is completely online and includes a very

Submit your manuscript here: http://www.dovepress.com/botanics-targets-and-therapy-journal 